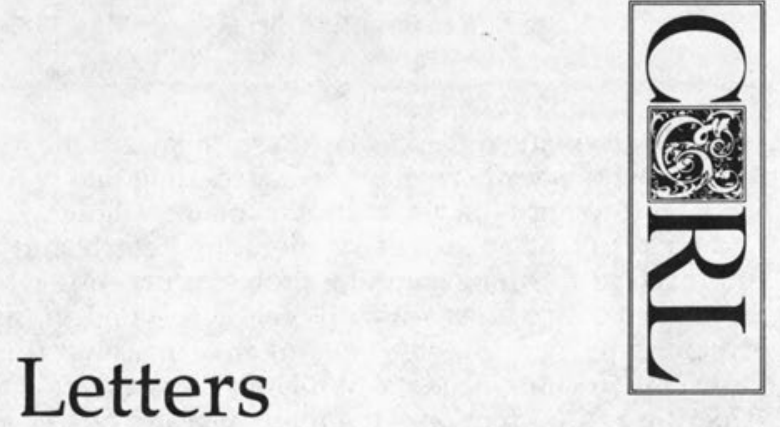

To the Editor:

Your editorial on the evaluation of reference question answering in the January issue of $C \mathcal{E} R L$ is very timely. Reference management, including evaluation of reference service, is a priority concern of the Reference and Adult Services Division of ALA, and the division's program at the Annual Conference in July will be on this topic. A number of articles on evaluation of question answering have been published fairly recently in the division's journal, $R Q$.

Some of your readers may not be aware that a rather new committee (founded in 1982) of RASD, the Evaluation of Reference and Adult Services Committee, has become an important forum for action and information exchange in this area. The committee has produced a sort of "roundup of recent developments" piece that appeared in the Spring 1983 issue of $R Q$. This piece resulted, in part, from our liaison with other ALA units with concerns and activities in this area (including ACRL), a liaison that continues actively. We have also gained all but final divisional approval for strengthening the evaluation components of the division's guidelines, "A Commitment to Information Services, " and we are cooperating in the planning for the division's conference program mentioned above.

One of the committee's responsibilities is to disseminate information to the profession. In that regard, we would point out that the Fall/Winter 1984 issue of The Reference Librarian is a theme issue on evaluation of reference services. Also, Ronald Powell published a comprehensive review of research in this field in the January-March 1984 issue of Library and Information Science Research. The recently published supplement to Marjorie Murfin's and Lubomyr Wynar's Reference Services: An Annotated Bibliographic Guide cites and annotates numerous reference evaluation studies.

Yet, with all these studies, more remains to be done. Objective and accurate data need to be gathered and to be considered in a variety of contexts, whether in quality circles of reference staff members, in planning and decision making by managers, or in the self-dialogue and reflection of individual reference librarians. We thank you for your support for insightful research and information sharing in this important area.

SARAH PRITCHARD, chair, and

CHARLES A. BUNGE, former chair

ALA/RASD Evaluation of Reference and Adult Services Committee

To the Editor:

I enjoyed your editorial in the January issue of CERL. All librarians need to reflect more on "how well they are doing." Unfortunately, I believe that reference work is as much an art as a science; performance is, thus, difficult to quantify. Although it doesn't directly address your concern, I believe Constance McCarthy's paper at last year's ACRL Conference ("Paraprofessionals, Student Assistants, and the Reference Clan'") goes a long way in describing how a reference department might maximize its effectiveness. Your concern is with the individual; McCarthy's is holistic. In any case, the Padres didn't win the series even with Tony Gywnn's startling batting average.

\title{
C. PAUL VINCENT
}

Ohio State University 
To the Editor:

I have just read your editorial "Performance at the Reference Desk" with great interest. In the past two years we have been exploring that perplexing issue-evaluating reference desk performance-in an attempt to answer "how well am I doing?"

As a result of an extensive literature search and many discussions regarding our approach to this long-standing problem; deciding what to measure and how, we have developed procedures which, I feel, go beyond those traditional evaluative techniques which have strictly involved quantitative measures. In our minds, these studies were too restrictive for our needs at William Paterson, and, as a result, we have developed a tripartite approach in our attempt to measure reference service, taking a more subjective and qualitative approach. Measurement instruments have been developed for patron survey, self-evaluation and supervisor observation. The criteria or factors which we feel are critical aspects of our service have been determined, and are the elements which we are hopeful will be measured by this approach.

NORMA LEVY

Head of Reference, William Paterson College of New Jersey

To the Editor:

Having experience in teaching English composition, and also in library instruction, I was pleased to see Constance Mellon's article "Process not Product in Course-integrated Instruction" (November 1984). The University of Tennessee at Chattanooga's program is exemplary, and Mellon's report makes a long overdue contribution to the literature. The logical refinement of course-integrated library instruction is to integrate the conceptual framework of the library component into the framework of the course. And yet, the process approach to writing has developed and guided freshman composition (a primary target for course-integrated instruction) for almost ten years now with minimal attention to teaching library use as a part of that process.

The search process model presented by Mellon (Figure 2: Basic Search Strategy for Beginning Composition Students) appears to be useful and teachable. The model addresses all the actions that are presumed necessary to effective use of the library, and offers effective strategies for the neophyte searcher, yet it remains simple and straightforward enough to present to students in clear, memorable visual aids.

However, more research is needed to validate this and similar models of the search process. We need to collect and analyze data on how research writers approach and use libraries. The techniques used to validate the writing process, such as protocol analysis, should also be applied to the search process.

JAMES T. NICHOLS

Public Services Librarian, Indiana University East

To the Editor:

I am writing in response to Karen Kinney's letter of comment (September 1984) on my article "Research and Library Skills: An Analysis and Interpretation" (March 1984). My initial perception was that anyone who had read my article carefully would realize that Ms. Kinney misinterpreted much of what I said. That being the case, a response on my part would be superfluous. A more careful reading of her letter, however, has convinced me that the attitudes or assumptions that underlay her reaction ought to be addressed, for they say much about a certain mindset among some in the profession that I personally find disturbing. I shall therefore approach her letter on two levels. I will address the issue of whether she understood correctly what I was saying, and I will direct my comments to the assumptions that seem to underlie her remarks.

Ms. Kinney's initial statement claimed that the logical deduction to be made from the data I presented was that bibliographic instruction is useless. That was not my conclusion. I stated that "undergraduate and graduate students, who are unable to operate with the broad knowledge and solid bibliographic base of research scholars, can find library skills 
valuable in initiating their first timid efforts at 'research.' " Further on in the same paragraph I said that "an introduction to the access and synthetic literature . . . can be for students a significant educational experience, even a revelation." I then devoted several paragraphs to pointing up ways in which librarians might improve the tone of bibliographic instruction units.

Ms. Kinney goes on to state that she disagrees "with the notion, attributed to instructors, that library assignments have no educational value." What I said was this: "Indeed, the limited extent of courses involving library components could be interpreted to indicate that many professors have doubts about the educational benefit of turning undergraduates loose on an independent literature search in a discipline they still scarcely understand-hence the emphasis in most undergraduate courses on assigned readings selected by the professor." Ms. Kinney did not convey the literal tenor of my original statement, which I stand behind. I would offer my personal experiences as an example of circumstances in which library assignments are not necessarily appropriate.

During the eleven years I was a college professor before entering librarianship, I taught courses to students at all levels, from freshmen through doctoral candidates. It would never have occurred to me to give a term paper to a class of 128 freshmen in a required Western Civilization course. In the first place, no one could reasonably supervise and grade that many papers, even with the one graduate grader I had been assigned. In the second place, hardly one percent of these students would go on to become history majors. And in the third place, the students had difficulty enough understanding an introductory text written specifically for freshmen. To attempt to introduce them to scholarly literature in the form of monographs or articles in learned journals identified through Historical Abstracts would have been absurd. Ms. Kinney's criticism of textbook use is ill-founded. Scholars write monographs and articles in learned journals for other scholars. They write texts and other synthetic works for undergraduate students.

Even in my upper level courses in Latin American history, fewer than half my students were history majors. Many were majoring in language, education, business, political science, anthropology, and a smattering of other disciplines. Few of these students would go on to graduate school. What need did they have to be forced to use the Handbook of Latin American Studies or HAPI, most of whose entries were in Spanish or Portuguese?

My philosophy was that if my students could read only six books during the semester, they would be better served if I selected those six books in order to guarantee some quality control and better integrate their readings into the themes that I had laid down for the course. I feel very deeply that my philosophy was perfectly defensible, though by no means do I criticize those who choose to teach in other ways, depending on their circumstances.

As I indicated earlier, I cite my own experiences only as an example. I am certain I could find numerous other courses on campus, ranging through most freshman and sophomore courses, courses in math, studio art, voice, photography, piano, dance, engineering, chemistry, physics, and so on, in which term papers or other kinds of library assignments are not particularly helpful. As a matter of fact, if every course on campus incorporated a library assignment utilizing the assistance of a reference librarian, not only would the library break under the strain but students would be subjected to essentially the same lectures ad nauseum and ad infinitum. In any case, the faculty have been hired to teach the credit courses in the degree-granting colleges, to determine the content of those courses, and to evaluate and to grade the students. The kinds of assignments they choose to give is their business, not ours. They are accountable to each other for how they teach, not to us in the library, who rarely have taught a credit course in anything other than library science.

Ms. Kinney goes on to assert that though the evidence indicates "that the faculty do not use indexes and other access tools," she contends that "many of them could actually profit from a systematic search of the indexes in their fields." I never stated in the article that the faculty do not use indexes, only that they find other techniques for gathering bibliography more efficient and helpful. There are few researchers who are unfamiliar with the leading 
indexing systems in their disciplines and who do not use them as needs dictate. If they do not consult these tools with greater frequency, it is because they do not find them as useful as other approaches. Neither Ms. Kinney nor I have the expertise to read a finished article on molecular biology, radioastronomy, or Byzantine history and decide if it was well researched or not. Nor can we determine whether the author used an index or not, nor if the article could have been better had the author used an index. Put simply, it is a waste of energy and breath to sit in the library offering gratuitous criticisms of how the faculty use or do not use reference tools in their research. All that we as librarians can do is make efforts to familiarize the faculty with potentially helpful sources. When and how they choose to use those tools is their concern, not ours. They will be held accountable by their peers in their own disciplines, not by librarians, who seldom have matching degrees and who have rarely published anything that would qualify as solid research.

Ms. Kinney concludes that the faculty need to be educated to understand "the mission and goals of libraries," which she does not define, and singles out my observation that the faculty dislike using microforms as an example of their "narrow and self-serving point of view.' I agree that there are some faculty with narrow and self-serving points of view, just as there are some librarians with narrow and self-serving points of view. I would point out, however, that no patrons like to use microforms. I would also quote myself with regard to microforms and other inconveniences that faculty find in libraries. "The preceding observations," I wrote, "are not meant to suggest that every library can, in every case, accommodate the ideals of research scholars. Practical and inescapable limitations of space and finances must often play the dominant role in decision making. "I see nothing in what I said that should have provoked the kind of reaction Ms. Kinney had.

Ms. Kinney's defensiveness about the faculty, her gratuitous criticisms of their teaching and research, and her claim that they do not understand the "mission and goals of libraries" cannot but make one wonder how she views the role of the library relative to the degree-granting colleges. She implies that the library's mission is to teach library skills because all educated people need such skills in our " information society." It would follow, it seems to me, that she expects the faculty to structure their courses in such a way as to give the library its chance to teach library skills. Indeed, Ms. Kinney expresses considerable resentment of faculty who do not give library assignments in all their courses. In all of this, I believe, she has the library tail wagging the teaching-college dog.

I have always understood that a university is an association of scholars dedicated to expanding, disseminating, and transmitting knowledge. The faculty are those who expand knowledge through their research, disseminate it through publications and conference activity, and transmit it to succeeding generations through the curriculum they have organized. The library's mission is derivative from and subordinate to that of the broader institution, whose heart, all rhetoric aside, is the degree-granting colleges.

The mission of the academic library is to support the research and teaching of the faculty by acquiring, organizing, and making available those materials of a bibliographic nature needed for scholarly research and teaching. The faculty have the prerogative of doing their research in whatever ways seem beneficial to them, subject to peer review within their respective disciplines. Likewise, they have the prerogative of organizing their courses as they see fit. Librarians are not trained as researchers and rarely have experience teaching a subject discipline. This being the case, our criticisms are an example of self-defeating behavior that avails nothing. Like it or not, the library is not a degree-granting college, and except in rare cases the bibliographic instruction it offers has no official recognition in the curriculum.

Bibliographic instruction in the pure sense is a legitimate activity for librarians, for it consists of arranging with those professors who desire it to assist their students in fulfilling the course objectives that they, the instructors, have laid down. The term "bibliographic" is appropriate, since it describes what librarians really do. We teach bibliographic techniques helpful in doing literature searches or tracking down limited kinds of "information," such as statistics. In other words, we are assisting the faculty in achieving 
curricular objectives that they have determined. Furthermore, it should come as no surprise that the faculty think in terms of teaching their subject disciplines, not some vague and ill-defined "library skills," a term I am coming to dislike even though I used it in my article.

The idea of the necessity of teaching "library skills" or "information-seeking skills" that will be of life-long benefit to the educated person rests on a series of assumptions that have never been supported with solid empirical data. There have been no good studies demonstrating that many people have a sincere interest, going beyond lip-service, in devoting time and energy to acquiring such skills when there are professional librarians trained to assist them. Likewise, there have been no good studies demonstrating that three or four hours of library instruction spread over four years of undergraduate education really suffice to impart library skills; that the average college graduate could pass a library skills test six months after graduating from college; that the average college graduate, no matter how heavily exposed to library skills in school, will ever be more than an occasional or sporadic user of the library in later life; or that librarians, who I suppose do possess such skills, are any better educated, better informed, or more knowledgeable than millions of other middle-class people successfully plying their trades as diplomats, politicians, businessmen, accountants, college professors, nurses, engineers, or architects. How significant is it, really, that any librarian-academic, public, or special-can pass a library skills test whereas Henry Kissinger cannot? How significant is it that Mr. Kissinger may not have used the Readers' Guide in the last forty years?

As a matter of fact, I think all librarians should ask themselves, seriously, how frequently they themselves use reference tools to satisfy personal information needs. They should ask themselves how frequently, if ever, they use the Readers' Guide, the Monthly Catalog, the Index to the New York Times, the Book Review Digest, or Masterplots to satisfy personal information needs. We complain that we do not see the faculty using the index tables frequently, but how often do we see our own colleagues in the library sitting at the index tables except in the line of duty? If librarians, who are familiar with hundreds of library tools, seldom use them except to help patrons or put together BI units, the assumption that exposing others to these tools will somehow precipitate more widespread use of them is highly questionable. At Wichita State, where more than 90 percent of the students are commuters who live near campus year-round, the most casual observer will notice that when classes are not in session, when students are no longer being obligated by their professors to go to the library, the library becomes a tomb. This is so after at least ten years of an active library instruction program.

Bibliographic instruction judiciously targeted on advanced-level professional or graduate courses designed to prepare students in discipline-based research methods can serve a valuable purpose. Ill-defined, poorly thought out, scattershot attempts to teach some abstract "library skills" or "information-seeking skills" may be a waste of human and material resources that libraries can ill afford when they are becoming increasingly hard pressed to justify the heavy investments they have been making in the seemingly bottomless pit of public service activity whose returns cannot be quanitified.

STEPHEN K. STOAN

Wichita State University 


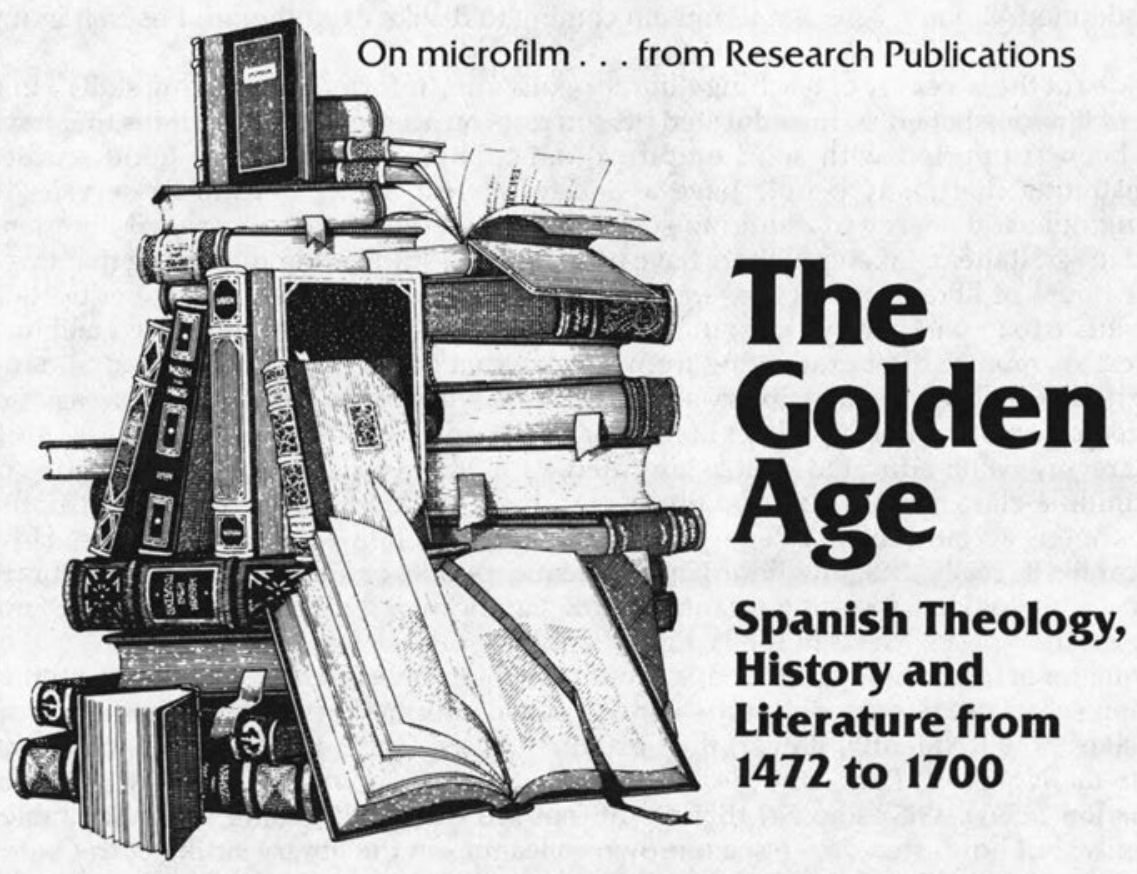

Spanish Rare Books of the Golden Age offers the opportunity to research the wide variety of literature written in Spain or composed in Spanish from 1472 to 1700 . Spanish Rare Books of the Golden Age includes drama, works on Jewish and Christian theology, medicine, and classical texts written in Latin and vernacular translations.

Spanish Rare Books of the Golden Age represents the writings of Boscán, Luis de León, Borja, Cervantes, Alemán, and others. Based on a collection at the Library of the University of Illinois, Spanish Rare Books of the Golden Age encompasses the development of prose and poetic styles from a period rich in religious, literary, and political works.

To order, or for more information on Spanish Rare Books of the Golden Age call or write:

Research Publications 12 Lunar Drive/Drawer AB Woodbridge, Ct 06525 (203) 397-2600

TWX: 710-465-6345

FAX: 203-397-3893
Outside North and South America P.O. Box 45

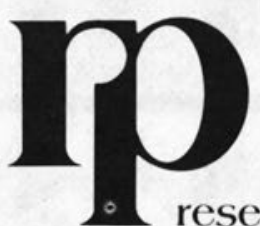

Reading, RG1 8HF England

TEL: 0734-583247

TELEX: 848336NADL G 